\title{
Hematological and morphometric blood value of four cultured species of economically important tropical foodfish
}

\author{
Genoefa Amália Dal'Bó1, Fernanda Garcia Sampaio², Marcos Eliseu Losekann², \\ Julio Ferraz de Queiroz², Alfredo José Barreto Luiz², Verena Hildegard Gyárfas \\ Wolf $^{3}$, Vitória Teodoro Gonçalves ${ }^{4}$ and Maria Lidia Carra ${ }^{4}$
}

\begin{abstract}
The use and validation of fish health monitoring tools have become increasingly evident due to aquaculture expansion. This study investigated the hematology and blood morphometrics of Piaractus mesopotamicus, Brycon orbignyanus, Oreochromis niloticus and Rhamdia quelen. The fish were kept for 30 days in 300-liter aquariums, after which they were anesthetized with benzocaine and blood was collected from caudal vessels. In comparison to other species, B. orbignyanus presented the highest hematocrit (Ht), RBC averages and Mean Corpuscular Volume (MCV) with a particular range of data. B. orbignyanus presented lower Ht, Hb, RBC averages and values, and Mean Corpuscular Hemoglobin Concentration (MCHC). Oreochromis niloticus presented lower $\mathrm{Ht}, \mathrm{Hb}, \mathrm{RBC}$ averages and values, and Mean Corpuscular Hemoglobin Concentration (MCHC). Rhamdia quelen and O. niloticus presented higher variation of White Blood Cells (WBC), neutrophils (N申), lymphocytes $(\mathrm{L} \phi)$, monocytes $(\mathrm{M} \phi)$ and thrombocytes (Trb). Data of large axes (LA), minor axes (MA), surface (SF) and volume (VL) are in the same variance range. This study has demonstrated that hematological variances can occur between animals of different species as well as of the same species.

O uso e validação de ferramentas para monitorar o estado de saúde dos peixes está se tornando mais evidente, devido à expansão da aquicultura. Este estudo investigou a hematologia e a morfometria do sangue de Piaractus mesopotamicus, Brycon orbignyanus, Oreochromis niloticus e Rhamdia quelen. Os peixes foram mantidos por 30 dias em aquários de 300 litros, após esse período os peixes foram anestesiados com benzocaína e o sangue coletado por punção caudal. Em comparação com outras espécies B. orbignyanus apresentou maiores médias de hematócrito (Ht), eritrócitos (Eri) e volume corpuscular médio (VCM) com um determinado intervalo de dados. Oreochromis niloticus apresentou menor média e valor de $\mathrm{Ht}$, $\mathrm{Hb}$, eritrócitos e concentração de hemoglobina corpuscular média (CHCM). Rhamdia quelen e O. niloticus apresentaram maior variedade de leucócitos (Leu), neutrófilos $(\mathrm{N} \phi)$, linfócitos $(\mathrm{L} \phi)$, monócitos $(\mathrm{M} \phi)$ e de trombócitos $(\mathrm{Trb})$. Dados de eixos maiores (EMA), eixos menores (EME), superfície (SF) e volume (VL) estão no mesmo intervalo de variação. Este estudo demonstrou que as variações hematológicas não ocorrem somente entre os animais de diferentes espécies, mas também entre os indivíduos da mesma espécie.
\end{abstract}

Keywords: Aquaculture, Fish stress, Health status, Hematological values, Tropical fish species.

\section{Introduction}

Aquaculture has become one of the most important activities of the Brazilian agribusiness industry. The use and validation of standardized non-lethal and inexpensive methods to monitor fish health are being considered as a major issue to ensure the expansion of fish production (Hrubec et al., 2000). Thus, the establishing of hematological values should be adopted as a reference to evaluate fish health status (Tavares-Dias et al., 2002). Hematology is considered as one of the key tools to assess the health status index of different species because it is provide a reliable evaluation via non-lethal means (Satheeshkumar et al., 2012). Despite its importance, there are few references regarding fish health status using such methodologies.

\footnotetext{
${ }^{1}$ Programa de Pós Graduação em Patologia Clínica Veterinária, Instituto Brasileiro de Veterinária, Rod. SP 340, km 127,5, Caixa Postal 69, 13820-000 Jaguaríuna, SP, Brazil. genoefadalbo@ig.com.br

${ }^{2}$ Empresa Brasileira de Pesquisa Agropecuária- Embrapa Meio Ambiente, Ministério da Agricultura, Pecuária e Abastecimento, Rod. SP 340, km 127,5, Caixa Postal 69, 13820-000 Jaguaríuna, SP, Brazil. (FGS) fernanda.sampaio@embrapa.br (corresponding author), (JFQ) julio.queiroz@embrapa.br, (MEL)marcos.losekann@embrapa.br, (AJBL) alfredo.luiz@embrapa.br

${ }^{3}$ Faculdade de Jaguariúna, Laboratório de Medicina Preventiva, Rod. SP 340, km 127, 13820-000 Jaguariúna, SP, Brazil. (VHGW) verenaprof@faj.br

${ }^{4}$ Graduação em Engenharia Ambiental, Faculdade Jaguariúna, Rod. SP 340, km 127, 13820-000 Jaguariúna, SP, Brazil. (VTG) vitoriatgoncalves@yahoo.com.br, (MLC)malidiacarra@gmail.com
} 
Despite blood parameters serving as a valuable indicator to evaluation the health conditions of aquatic organisms, it can be quite difficult due to several internal and external factors. According to Fernandes \& Mazon (2003), hematological parameters of fish are closely related to environmental and biological factors. Physiological changes could be a consequence of stress, and a number of hematological indexes are used to identify these conditions. According to Adams et al. (1996) the measurement of blood parameters can be used as a tool for monitoring the biological condition of fish in response to changes related to nutrition, water quality and disease. Other factors such as behavior, habitat and climate can also influence hematological values (Tavares-Dias \& Moraes, 2004).

Tavares-Dias \& Moraes (2006) reported the urgent need to create reliable databases for economically important species. Thrall et al. (2007) considered that the establishment of hematological status based on data obtained from healthy animals is fundamental to characterize a normal range variation. According to Leatherland et al. (1998) before using hematological parameters to evaluation the physiological condition of different species of fish it is necessary to establish a reference index.

The culture of different native species of fish by aquaculture is increasing in Brazil given their comparative advantages in relation to exotic species. Three native species of major importance and cultured in different regions of Brazil were selected for this study. The lack of information and limited research on the physiology of economically important tropical fish species are considered a disadvantage for the productive sector (Hahn-Von-Hessberg et al., 2011). The Siluriform Rhamdia quelen (Quoy \& Gaimard, 1824), known in Brazil as jundiá, is well distributed in South America and its culture has been intensified via induced reproductive process with good results (Gomes et al., 2000). According to Radünz-Neto (1981) R. quelen presents good feed conversion ratio and presents a high demand on the regional market. The piracanjuba, Brycon orbignyanus (Valenciennes, 1850), is well distributed in South America (Lima, 2003), and it well accepted in different and fastgrowing markets (Lorenz, 2010). The serrasalmid fish, Piaractus mesopotamicus (Holmberg, 1887), known in Brazil as pacu, is a migratory species and it is distributed throughout South America. Piaractus mesopotamicus is one of the most important freshwater fish commercialized in Brazil due to its ability to adapt to different aquaculture systems, fast growth rate and organoleptic qualities. The fourth species selected for this study was the non-native $O$. niloticus, Oreochromis niloticus (Linnaeus, 1758). Oreochromis niloticus is the most suitable fish to be produced in intensive systems, especially in tropical countries like Brazil. According to the Ministério da Pesca e Aquicultura, O. niloticus is the major species cultured in Brazil (MPA, 2012).

The objective of this study was to determine the hematological values of four Teleostei species of economic importance, and to provide a basic hematological profile for future comparative investigation. In addition the data obtained can be used for monitoring the health status of the four species offish selected. The present study has determined the hematocrit, hemoglobin, red blood cell, the Mean Corpuscular Volume, the Mean Corpuscular Hemoglobin Concentration, total and differential white blood cells, thrombocyte and the morphometry of RBC of R. quelen, $O$. niloticus, B. orbignyanus and P. mesopotamicus.

\section{Material and Methods}

Fish and sample preparation. Juveniles, from 40 to 50 of each species, were obtained from Piscicultura Polettini, Mogi Mirim, SP, Brazil. After five months of maintenance in four glass aquariums $(960 \mathrm{~L})$, the different species of fish were transferred to two experimental glass aquariums (300 L) for a period of 30 days. All experimental aquariums were connected to a closed water recirculation system, well aerated, and linked a constant temperature monitoring system. During the experimental period, all fish were fed ad libitum twice a day with commercial dry pellets Pirá 32, from Guabi, Orlândia, SP, Brazil, containing 32\% of crude protein. Water quality variables were measured on a daily basis for each aquarium via Horiba U10 multiparameter probe. The following means ( \pm standard deviation; SD) were obtained for the water quality variables measured during the experimental period: $\mathrm{pH} 6.21 \pm 0.54$, dissolved oxygen $7.07 \pm 1.08\left(\mathrm{mg} . \mathrm{L}^{-1}\right)$, temperature $25.92 \pm 0.65$ (C). An HACH DR/200 spectrophotometer was used to measured other variables such as, ammonia $0.12 \pm 0.18$ (mg. $\left.\mathrm{L}^{-1}\right)$, nitrite $0.21 \pm 0.07\left(\mathrm{mg} . \mathrm{L}^{-1}\right)$, nitrate $37.10 \pm 7.80$ (mg. $\left.\mathrm{L}^{-1}\right)$ and total phosphorus $9.60 \pm 1.93\left(\mathrm{mg} . \mathrm{L}^{-1}\right)$.

At the end of the experimental period, all fish were anesthetized with benzocaine $\left(65 \mathrm{mg} \cdot \mathrm{L}^{-1}\right)$. Upon sedation, blood was collected from their caudal vessel using a heparinized syringe needle gauge $22 \mathrm{~L} 1 \frac{1}{2}$ in and around 1 to $2 \mathrm{~mL}$ of blood was collected from each individual. Blood smears were made immediately after collection, and then blood was disposed in microtubes for further analytical procedure. Except differential count of WBC, the other procedures were made immediately after collection. The mean weight $( \pm \mathrm{SD})$ and the mean length $( \pm \mathrm{SD})$ of the animals were: $R$. quelen $101.91 \pm 35.23 \mathrm{~g}$ and $17 \pm 2 \mathrm{~cm} ; O$. niloticus $191.83 \pm 66.02 \mathrm{~g}$ and $18 \pm 2 \mathrm{~cm} ;$ B. orbignyanus $151.08 \pm 40.49 \mathrm{~g}$ and $19 \pm 2 \mathrm{~cm}$, and P. mesopotamicus 98.88 $\pm 22.19 \mathrm{~g}$ and $13 \pm 1 \mathrm{~cm}$. The methodologies adopted for this study were in conformity with the Brazilian Guidelines for Animal Care and Use for Scientific and Educational Purposes. The experiment protocol was approved by the Ethics Committee on Animal Use adopted by Embrapa Meio Ambiente (protocol N.007/2012).

Erythrogram and leukogram. Hematocrit (Ht) was determined by microhematocrit centrifugation technique. Hemoglobin concentration was measured by cyanomethahemoglobin method using a commercial kit 
from Labtest Diagnóstica, Lagoa Santa, MG, Brazil. The red blood cells (RBC), white blood cells (WBC) plus thrombocytes were determined optically with a Neubauer chamber using the Natt \& Herrick (1952) solution as diluent. The mean cell volume (MCV) and the mean cell hemoglobin concentration (MCHC) were calculated from the $\mathrm{Ht}, \mathrm{Hb}$ and $\mathrm{RBC}$.

Differential counting of WBC was performed by means of panoptic blood smear. The differential counts were performed in homogeneous areas by counting 200 leukocytes on each smear according to Natt \& Herrick (1952). The total number of leukocytes was obtained by subtracting the percentage of thrombocytes from the total of leukocytes plus thrombocytes counted with a Neubauer chamber. With the total leukocytes number $(\mathrm{WBC} ; / \mu \mathrm{L})$ and the relative leukocytes number (\%) it was possible to calculate the absolute number $(/ \mu \mathrm{L})$ of neutrophils $(\mathrm{N} \phi ; / \mu \mathrm{l})$, lymphocytes $(\mathrm{L} \phi ; / \mu \mathrm{l})$, monocytes $(\mathrm{M} \phi ; / \mu \mathrm{l})$, eosinophils $(\mathrm{E} \phi ; / \mu \mathrm{l})$, basophils $(\mathrm{B} \phi ; / \mu \mathrm{l})$, special granulocytic cells $(\mathrm{SGC} ; / \mu \mathrm{l})$ and thrombocytes (Trb; $/ \mu \mathrm{l})$ found in the blood smear samples, as proposed by Hrubec \& Smith (2010). In the text the abbreviations are: $\mathrm{B} \phi$ - basophils, $\mathrm{E} \phi$ - eosinophils, Ht - hematocrit, L $\phi$ - lymphocytes, LA - larger axes, M $\phi$ - monocytes, MA - minor axes, MCHC - mean cell hemoglobin concentration, MCV - mean cell volume, N $\phi$ - neutrophils, Occ - occurrence, RBC - red blood cells, SF - surface, SGC - special granulocitic cells, Trb - thrombocytes, VL - volume and WBC - white blood cells.

Red blood cell morphometry. For the RBC morphometry, the larger axes $(\mathrm{LA} ; \mu \mathrm{m})$ and the minor axes $(\mathrm{MA} ; \mu \mathrm{m})$ of 50 random cells were measured in 11 - 15 smears for each species of fish, using a microscope and Toup Tek Toup View VX86 program. The volume $\left(\mathrm{VL} ; \mu \mathrm{m}^{3}\right)$ and surface area (SF; $\mu \mathrm{m}^{3}$ ) were calculated based on the methodology proposed by Turrell (1946), and the following formulas were applied:

$$
\begin{gathered}
a=\frac{1}{2}: b=\frac{1}{2}: \text { where: } a=\text { minor axes and } b=\text { larger axes } \\
\text { Surface }=2 a^{2}\left(1+\frac{c}{a e} \sin ^{-1} e\right) ; \text { where: } e^{-1}=1-\frac{\mathrm{a}^{2}}{c^{2}} \\
\text { Volume }=\frac{4}{3} a^{2} . b
\end{gathered}
$$

Data analysis. Data presented as mean and standard deviation (SD; \%), minimum and maximum values and occurrence (Occ, \%). Data amplitude was obtained by the subtraction of maximum and minimum values.

\section{Results}

The experimental period recorded nil mortality for any experimental group. Hematological parameters and blood morphometry of all fish species are presented in Tables 1-3 and Fig. 1. Table 1 presents the erythrogram data of hematocrit, hemoglobin, $\mathrm{RBC}, \mathrm{MCV}$ and $\mathrm{MCHC}$ of each fish species. Brycon orbignyanus presented the highest means of Ht, RBC and MCV in comparison to other species. Brycon orbignyanus also presented the highest value of $\mathrm{Ht}$, $\mathrm{Hb}$ and $\mathrm{MCV}$. However, O. niloticus presented the lowest averages and values of $\mathrm{Ht}, \mathrm{Hb}, \mathrm{RBC}$ and $\mathrm{MCHC}$ where compared to the three other species.

The Ht and RBC range data obtained for B. orbignyanus did not match the values of the three other species selected for this study. Brycon orbignyanus presented a higher oxygen transport capacity because of its higher $\mathrm{Hb}$ values. Brycon orbignyanus was also the most active when compared to the other three species. However, the minimum and maximum ranges of $\mathrm{RBC}, \mathrm{Ht}$ and $\mathrm{Hb}$ for $O$. niloticus, $R$. quelen and $P$. mesopotamicus fish were included in the same interval. $\mathrm{MCV}$ and $\mathrm{MCHC}$ ranges for the four species were in the same intermission period. Rhamdia quelen presented the highest $\mathrm{CV}$ of $\mathrm{Ht}, \mathrm{Hb}$ and $\mathrm{RBC}$, with higher $\mathrm{Ht}$ and $\mathrm{Hb}$ data amplitude. Piaractus mesopotamicus presented the lowest $\mathrm{Ht}, \mathrm{Hb}$ and $\mathrm{MCV}$ data amplitude.

In the present study all fish showed WBC in a similar range. Despite the occurrence of WBC, Rhamdia quelen presented the highest mean. Oreochromis niloticus presented the highest value, amplitude of data and CV of WBC. Piaractus mesopotamicus presented the lowest value, lowest mean value, amplitude and CV of WBC.

Oreochromis niloticus presented the highest value and mean of L $\phi$, on the other hand Oreochromis niloticus presented the lowest value and mean of L $\phi$. Rhamdia quelen showed the highest mean and the lowest CV of $\mathrm{N} \phi$. Brycon orbignyanus presented the highest value and data amplitude of N申. Piaractus mesopotamicus presented the lowest value, mean, data amplitude, and the highest $\mathrm{CV}$ of N $\phi$. Except for P. mesopotamicus, with $67 \%$ of occurrence for $\mathrm{N} \phi$, the other species presented $100 \%$ of occurrence. Rhamdia quelen presented higher $\mathrm{CV}$ for $\mathrm{M} \phi$, with $82 \%$ of occurrence. The Oreochromis niloticus presented the highest value and amplitude of $\mathrm{M} \phi$, with $100 \%$ of occurrence. Brycon orbignyanus presented the lowest CV and the highest mean of M $\phi$. Piaractus mesopotamicus presented the lowest value, mean and amplitude of $\mathrm{M} \phi$, with $87 \%$ of occurrence. Oreochromis niloticus presented the highest $\mathrm{CV}$ of E $\phi$, with $13 \%$ of occurrence. Brycon orbignyanus presented the highest value, mean and $\mathrm{CV}$

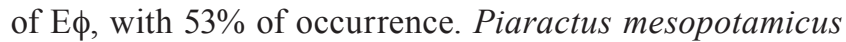
presented the lowest amplitude and value of E $\phi$, with $40 \%$ of occurrence. Only one $R$. quelen presented E $\phi$, with $9 \%$ of occurrence. Rhamdia quelen was the unique species that presented the basophils with $18 \%$ of occurrence.

Rhamdia quelen presented the highest value, mean amplitude of SGC, with $64 \%$ of occurrence. Brycon orbignyanus presented the highest $\mathrm{CV}$ and lowest value of SGC, with $20 \%$ of occurrence. Piaractus mesopotamicus presented the lowest $\mathrm{CV}$, mean and amplitude for SGC, with $67 \%$ of occurrence. Not a single $O$. niloticus evaluated presented SGC cells. The Trb was the most common cell found for the four species studied after RBC. 
Rhamdia quelen and $O$. niloticus were species with higher variation for $\mathrm{WBC}, \mathrm{N} \phi, \mathrm{L} \phi, \mathrm{M} \phi$ and $\mathrm{Trb}$. Oreochromis niloticus presented higher variation of $\mathrm{E} \phi$ and $R$. quelen showed higher variation of $\mathrm{B} \phi$, being the exclusive species that presented this kind of cells.

Data obtained for LA, MA, SF and VL were in the same variance range. Despite some similarities, $P$. mesopotamicus presented higher values of LA, MA, SF and VL, and larger cells where compared to the other studied species. Brycon orbignyanus presented lesser value of MA and VL and $R$. quelen lesser value of LA and SF. Oreochromis niloticus presented higher CV of LA, MA, SF and VL. Piaractus mesopotamicus presented lesser CV of LA, MA, SF and VL.

Table 1. Sample number $(\mathrm{N})$, mean \pm standard deviation $(\mathrm{SD})$, and minimum and maximum of hematocrit (Ht; \%), hemoglobin $\left(\mathrm{Hb} ; \mathrm{g} / \mathrm{dL}^{1}\right)$, red blood cell $\left(\mathrm{RBC} ; \mathrm{x} 10^{6} / \mu \mathrm{l}\right)$, Mean Corpuscular Volume (MCV; fL) and Mean Corpuscular Hemoglobin Concentration (MCHC; \%) of Rhamdia quelen, Oreochromis niloticus, Brycon orbignyanus and Piaractus mesopotamicus maintained under controlled conditions for a period of 30 days.

\begin{tabular}{|c|c|c|c|c|c|}
\hline \multicolumn{2}{|c|}{ Species } & \multirow{2}{*}{$\begin{array}{c}\text { Rhamdia quelen } \\
11\end{array}$} & \multirow{2}{*}{$\begin{array}{c}\text { Oreochromis niloticus } \\
15\end{array}$} & \multirow{2}{*}{$\frac{\text { Brycon orbignyanus }}{15}$} & \multirow{2}{*}{$\frac{\text { Piaractus mesopotamicus }}{15}$} \\
\hline & $\mathrm{N}$ & & & & \\
\hline \multirow{2}{*}{ Ht $(\%)$} & Mean \pm SD & $33 \pm 5$ & $29 \pm 4$ & $50 \pm 3$ & $36 \pm 3$ \\
\hline & Min - Max & $24-43$ & $21-36$ & $44-56$ & $32-42$ \\
\hline \multirow{2}{*}{$\mathrm{Hb}\left(\mathrm{g} / \mathrm{dL}^{1}\right)$} & Mean \pm SD & $7.55 \pm 1.4$ & $6.48 \pm 0.7$ & $11.35 \pm 0.9$ & $8.05 \pm 0.5$ \\
\hline & Min - Max & $5.38-9.57$ & $4.75-7.7$ & $9.30-12.7$ & $7.15-8.7$ \\
\hline \multirow{2}{*}{$\mathrm{RBC}\left(\mathrm{x} 10^{6} / \mu \mathrm{l}\right)$} & Mean \pm SD & $2.11 \pm 0.6$ & $1.70 \pm 0.4$ & $2.56 \pm 0.5$ & $2.57 \pm 0.5$ \\
\hline & Min - Max & $1.4-3.6$ & $1.03-2.3$ & $1.70-3.5$ & $1.60-3.8$ \\
\hline \multirow{2}{*}{ MCV (fL) } & Mean \pm SD & $161.0 \pm 29.8$ & $180.01 \pm 40.4$ & $202.88 \pm 41.3$ & $147.31 \pm 29.6$ \\
\hline & Min - Max & $104.4-212.3$ & $119.14-252.4$ & $145.21-284.1$ & $92.34-200.0$ \\
\hline \multirow{2}{*}{ MCHC (\%) } & Mean \pm SD & $23.0 \pm 1.5$ & $22.18 \pm 2.2$ & $22.59 \pm 1.1$ & $22.29 \pm 1.6$ \\
\hline & Min - Max & $20.4-25.4$ & $18.3-27.6$ & $20.20-24.5$ & $19.85-25.3$ \\
\hline
\end{tabular}

Table 2. Sample number (N), mean \pm standard deviation (SD), minimum and maximum and occurrence (\%) of white blood cells (WBC; / $\mu$ l), neutrophils $(\mathrm{N} \phi ; / \mu l)$, lymphocytes $(\mathrm{L} \phi ; / \mu \mathrm{l})$, monocytes $(\mathrm{M} \phi ; / \mu \mathrm{l})$, eosinophils $(\mathrm{E} \phi ; / \mu \mathrm{l})$, basophils $(\mathrm{B} \phi$; $/ \mu 1)$, Special Granulocitic Cell (SGC; / $\mu$ l) and thrombocytes (Trb; $/ \mu 1$ ) of Rhamdia quelen, Oreochromis niloticus, Brycon orbignyanus and Piaractus mesopotamicus maintained under controlled conditions for a period of 30 days. * E $\phi$ was found in one individual; na $=$ not applicable.

\begin{tabular}{|c|c|c|c|c|c|}
\hline & & Rhamdia quelen & Oreochromis niloticus & Brycon orbignyanus & Piaractus mesopotamicus \\
\hline & $\mathrm{N}$ & 11 & 15 & 15 & 15 \\
\hline \multirow{3}{*}{ WBC $(/ \mu 1)$} & Mean \pm SD & $29.4 \pm 17.5$ & $26.9 \pm 16.2$ & $16.4 \pm 7.6$ & $12.2 \pm 3.2$ \\
\hline & Min - Max & $10.3-67.2$ & $9.2-68.7$ & $7.5-29.5$ & $6.5-17.8$ \\
\hline & Occurrence (\%) & 100 & 100 & 100 & 100 \\
\hline \multirow{3}{*}{$\mathrm{L} \phi(/ \mu \mathrm{l})$} & Mean \pm SD & $22.6 \pm 15.6$ & $23.2 \pm 14.2$ & $11.2 \pm 6.5$ & $11.7 \pm 3.3$ \\
\hline & Min - Max & $4.7-58.0$ & $8.2-58.7$ & $4.5-27.6$ & $5.8-17.6$ \\
\hline & Occurrence (\%) & 100 & 100 & 100 & 100 \\
\hline \multirow{3}{*}{$\mathrm{N} \phi(/ \mu 1)$} & Mean \pm SD & $5.9 \pm 3.7$ & $2.7 \pm 2.0$ & $4.3 \pm 4.2$ & $224 \pm 294$ \\
\hline & Min - Max & $1.6-13.0$ & $603-8.9$ & $904-15.2$ & $50-1.0$ \\
\hline & Occurrence $(\%)$ & 100 & 100 & 100 & 67 \\
\hline \multirow{3}{*}{$\mathrm{M} \phi(/ \mu 1)$} & Mean \pm SD & $663 \pm 1.1$ & $865 \pm 916$ & $907 \pm 427$ & $243 \pm 160$ \\
\hline & Min - Max & $51-3.7$ & $109-3.8$ & $302-1.7$ & $50-636$ \\
\hline & Occurrence $(\%)$ & 82 & 100 & 100 & 87 \\
\hline \multirow{3}{*}{$\mathrm{E} \phi(/ \mu \mathrm{l})$} & Mean \pm SD & 134 & $298 \pm 302$ & $333 \pm 211$ & $110 \pm 70$ \\
\hline & Min - Max & $134^{*}$ & $84-512$ & $130-747$ & $50-238$ \\
\hline & Occurrence $(\%)$ & 9 & 13 & 53 & 40 \\
\hline \multirow{3}{*}{$\mathrm{B} \phi(/ \mu \mathrm{l})$} & Mean \pm SD & 162 & 0 & 0 & 0 \\
\hline & Min - Max & $51-272$ & 0 & 0 & 0 \\
\hline & Occurrence $(\%)$ & 18 & na & na & na \\
\hline \multirow{3}{*}{$\mathrm{SGC}(/ \mu 1)$} & Mean \pm SD & $365 \pm 281$ & 0 & $129 \pm 131$ & $112 \pm 59$ \\
\hline & Min - Max & $113-841$ & 0 & $46-279$ & $50-208$ \\
\hline & Occurrence (\%) & 64 & na & 20 & 67 \\
\hline \multirow{3}{*}{$\operatorname{Trb}(/ \mu l)$} & Mean \pm SD & $48.6 \pm 16.8$ & $35.9 \pm 14.4$ & $37.9 \pm 7.8$ & $30.0 \pm 7.8$ \\
\hline & Min - Max & $21.9-75.9$ & $10.3-66.8$ & $22.8-54.1$ & $16.1-41.6$ \\
\hline & Occurrence (\%) & 100 & 100 & 100 & 100 \\
\hline
\end{tabular}


Table 3. Sample number $(\mathrm{N})$, mean \pm standard deviation (SD), coefficient of variation $(\mathrm{CV})$, and minimum and maximum of larger axes $(\mu \mathrm{m})$, minor axes $(\mu \mathrm{m})$, surface $\left(\mu \mathrm{m}^{3}\right)$ and volume $\left(\mu \mathrm{m}^{3}\right)$ of red blood cells of Rhamdia quelen, Oreochromis niloticus, Brycon orbignyanus and Piaractus mesopotamicus maintained under controlled conditions for a period of 30 days. Values are means of 50 random cells measured in $11-15$ blood smears.

\begin{tabular}{cccccc}
\hline & & Rhamdia quelen & Oreochromis niloticus & Brycon orbignyanus & Piaractus mesopotamicus \\
\hline & $\mathrm{N}$ & 11 & 15 & 15 & 15 \\
\hline \multirow{2}{*}{ Larger axes $(\mu \mathrm{m})$} & Mean \pm SD & $12.1 \pm 0.3$ & $13.2 \pm 0.6$ & $14.4 \pm 0.3$ & $15.0 \pm 0.4$ \\
& Min - Max & $9.5-14.5$ & $10.2-16.7$ & $11.1-17.4$ & $12.4-18.7$ \\
\multirow{2}{*}{ Minor axes $(\mu \mathrm{m})$} & Mean \pm SD & $9.3 \pm 0.3$ & $9.3 \pm 0.4$ & $8.7 \pm 0.2$ & $9.8 \pm 0.2$ \\
& Min - Max & $7.1-12.0$ & $6.5-11.7$ & $6.2-10.6$ & $7.9-13.2$ \\
Surface $\left(\mu \mathrm{m}^{3}\right)$ & Mean \pm SD & $317.0 \pm 36.4$ & $343.1 \pm 43.4$ & $337.3 \pm 30.7$ & $400.6 \pm 36.5$ \\
& Min - Max & $207.9-461.3$ & $228.9-539.2$ & $215.1-455.1$ & $293.6-594.6$ \\
Volume $\left(\mu \mathrm{m}^{3}\right)$ & Mean \pm SD & $545.2 \pm 95.0$ & $612.6 \pm 119.4$ & $585.4 \pm 84.0$ & $765.8 \pm 108.7$ \\
& Min - Max & $289.9-936.2$ & $325.2-1,204.3$ & $276.8-912.7$ & $467.6-1,394.9$ \\
\hline
\end{tabular}

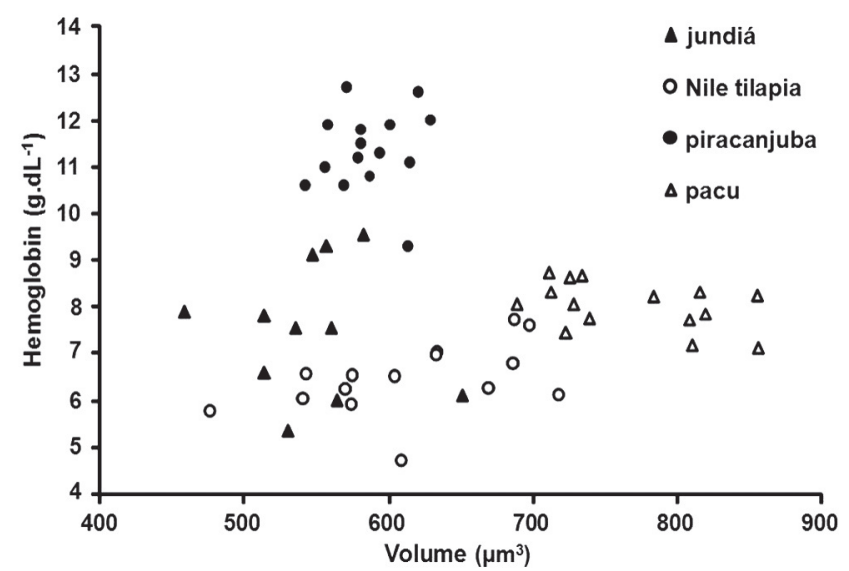

Fig. 1. Volume $\left(\mu \mathrm{m}^{3}\right)$ of red blood cell and hemoglobin (g.dL ${ }^{-1}$ ) of jundiá (Rhamdia quelen), Nile tilapia (Oreochromis niloticus), piracanjuba (Brycon orbignyanus) and pacu (Piaractus mesopotamicus) maintained under controlled conditions for a period of 30 days. Values are means of 50 random cells measured in 11-15 blood smears.

\section{Discussion}

The water quality parameters were kept constant and were within the acceptable levels for fish culture (Boyd, 1990). Hemoglobin levels tend to be relatively constant within the same species, but may considerably differ between different species (Cameron, 1969; Larsson et al., 1976). Nevertheless, depending on the physiological conditions of the fish, hematological variations can occur between animals of different species as well as between individuals of equal species (Mahajan \& Dheer, 1979). The assortment of hemoglobin within species suggests an association with blood oxygen transport as an index of the aerobic metabolic capabilities of fish (Graham et al., 1985).

Hematocrit variation can be used to exemplify variations in fish hematology. According to Borges (2005), Ht follows the evolutionary aspects of fish, indicating that low values occur in primitive species living in lentic environments and with sedentary behavior, whereas higher values occur in active marine species. Ht values can also increase as a result of splenic contraction, and as a result of RBC swelling (Hrubec \& Smith, 2010). Ht can also vary in fish according to their swimming performance. Wilhelm Filho et al. (1992) observed that active fish species presented higher $\mathrm{Ht}, \mathrm{Hb}$ and $\mathrm{RBC}$, where compared to less active fish species.

The high heterogeneity of the data presented by $R$. quelen fish showed that the use of hematological parameters to evaluation fish health status should be carefully studied in order to comprehend the intrinsic variations to only then be used to establish a pattern. The opposite is also true where hematological results obtained for the $P$. mesopotamicus showed the higher homogeneity of erythrogram data. However, reliable conclusions require sufficient number of samples to obtain a significant evaluation.

Although a number of studies related to fish hematology have been conducted, definition of reference normal value ranges are quite difficult and complicated (Vácha, 1980). Some previous studies with reliable data on hematology of teleost species have been conducted. Among them, it is important to highlight the data compiled by Tavares-Dias \& Moraes (2004), who published extensive information about the hematological parameters of teleost species. Comparing the present data to previous studies, there is evident agreement with the previously published range, though some errors in hemoglobin concentration and hematocrit value variances for the same species can be noted. Such circumstances are common and could be related to different blood process techniques and different Brazilian regions. The hematological parameters of $B$. orbignyanus were similar to those found by Tavares-Dias \& Moraes (2006), who studied the same species cultured in an intensive production system. There are also similarities between the data obtained for $O$. niloticus and the data found by Tavares-Dias et al. (2000) and Ueda et al. (1997). There are also similarities for P. mesopotamicus in the present study to those found by Sampaio et al. (2012) and Tavares-Dias \& Mataqueiro (2004). In addition, more similarities were found for $R$. quelen where compared to the findings obtained by Foresti et al. (1977) and Tavares-Dias et al. (2002). 
The lymphocytes are the most common leukocytes found in healthy teleost, and they represent an important function in the cell immunity of fish (Thrall et al., 2007). In this study, the L $\phi$ was the most common leukocyte observed for the studied species, followed by $\mathrm{N} \phi, \mathrm{M} \phi$ and E $\phi$. It corroborates the data obtained by Carvalho et al. (2009) related to Auchenipterus nuchalis (Spix \& Agassiz, 1829), Psectrogaster amazonica (Eigenmann \& Eigenmann, 1889) and Squaliforma emarginata (Valenciennes, 1840), fish species native of rio Tocantins basin. However, a little different where compared to data obtained by Hrubec \& Smith (2010) who affirmed that lymphocytes are the most abundant leukocytes in fish, followed by monocytes, neutrophils and eosinophils.

According to Thrall et al. (2007) neutrophils, eosinophils, macrophages and monocytes present relevant importance in teleost species as part of the inflammatory process, although there is still some disagreement as to their function. Tavares-Dias \& Moraes (2006) also observed higher values of $\mathrm{N} \phi$ for $B$. orbignyanus where compared with $P$. mesopotamicus kept in ponds (Tavares-Dias \& Mataqueiro, 2004). Hrubec \& Smith (2010) also affirmed that the occurrence of basophils in fish is occasional. According to Ranzani-Paiva \& Silva-Souza (2004), the role of basophils in their organism remains little known, but appears to be involved in the allergic process given their histamine content (Hrubec \& Smith, 2010).

According to Tavares-Dias \& Moraes (2004), the SGC, like other leucocytes, do not have a well described function in fish, but it has been suggested that they occur in fish infected by parasites. Ueda et al. (2001), describe thrombocytes as the most abundant blood cell after erythrocytes corroborating with the present data. The role of the thrombocytes in clotting is well described. Tavares-Dias et al. (1999) suggested that thrombocytes also participate in the inflammatory exudates and present phagocytic activity. In contrast to mammalian platelets, the thrombocytes of fish are complete cells (Tavares-Dias \& Moraes, 2004).

Despite the variation, the values of WBC and Trb, and the absolute number of $\mathrm{L} \phi, \mathrm{N} \phi, \mathrm{M} \phi$ and $\mathrm{E} \phi$ for $O$. niloticus in the present study are in the same range of values of those found by Hrubec et al. (2000) where they studied hybrid tilapia (O. niloticus x O. mossambicus x O. aureus) in high density and fed with commercial feed. Hrubec et al. (2000) also does not report the occurrence of $\mathrm{B} \phi$ and SGC in Oreochromis niloticus. On the other hand, the values obtained in this study were superior to those found by Ishikawa et al. (2008), where a direct methodology to count WBC for $O$. niloticus maintained in ponds was used. The mean value of WBC for $O$. niloticus, in the present study, was lower than the findings of Falcon et al. (2008) in the control group. The maximum value of $\mathrm{WBC}$ for $O$. niloticus in the present study was similar to those found by the same authors in the control group. In the present study, the Trb of the $O$. niloticus is in the same range as that found by Azevedo et al. (2006) for the same species. The values of
WBC, Trb and $\mathrm{M} \phi$ for B. orbignyanus in the present study are in accordance with those reported by Tavares-Dias \& Moraes (2006) for the same species. However, the values of $\mathrm{L} \phi$ and $\mathrm{N} \phi$ in the present study were higher for the values of $\mathrm{L} \phi$ and lesser for N $\phi$. Another difference is that in the present study $B$. orbignyanus presented the SGC.

The leukocytes are useful for assessing the immune system and variations in the proportion of these cells are considered normal (Tavares-Dias \& Moraes, 2006). The role of leukocytes is known for some vertebrates and despite the studies related to fish leukocyte function, there is no general classification (Tavares-Dias, 2009). Some errors and lack of standards for analytical methods make it very difficult to compare the results between authors and species.

Smith (1925) states that RBC size varies inversely with animal metabolic activity. Szarski (1970) concludes that red blood cell size has an adaptive value; therefore, any adaptive reduction in metabolic rate would be followed by a tendency toward an increase in cell size. The variation in hematological parameters, such as RBC size and volume, can be verified not only for different species but also for the same species in different niches, inducing physiological adaptation (Campbell \& Murru, 1990). There are few studies focused on characterizing the hematological pattern of fish species which make the comparison of values difficult. Holland (1970) has demonstrated that the rate of oxygen in combination with hemoglobin is inversely related to cell volume. Thus, the benefits gained from increasing cell size would have to be balanced against the costs of slowing the rate at which oxygen enters or leaves the cell. A functional basis for this relationship is found in larger surface area of volume ratios and shorter diffusion distances, allowing for more rapid oxygenation, and the deoxygenation of hemoglobin to the extent erythrocyte volume decreases (Holland \& Forster, 1966; Jones, 1979). According to these affirmatives, the results obtained by this study showed that P. mesopotamicus should be the less active species because it presented the larger RBC volume. However, $R$. quelen and $B$. orbignyanus appear to be the most active species given their lower RBC volumes. Although B. orbignyanus, which presented the higher hemoglobin concentration, is not necessarily the species with the larger RBC. It was also possible to observe that despite the VL of all four studied species being at the same range, there was a grouping of values for $B$. orbignyanus and $P$. mesopotamicus, while $O$. niloticus and $R$. quelen presented dispersed values.

Relatively, little is known about the size of red blood cells of tropical teleost fish. Hansen \& Wingstrand (1960) reported the size of red blood cells for a number of species. Studies by Fletcher (1975) and Smith (1974), with nineteen shallow-water species, found mean cell volume ranging from approximately 100 to $200 \mu^{3}$. For this study, the volume range has varied from 276.86 to $1,394.92 \mu \mathrm{m}^{3}$. Erythrocyte volume has varied more than 13 folds among teleost species, and numerous authors have reported an inverse relationship between erythrocyte size and aerobic swimming ability 
(Graham et al., 1985; Wilhelm Filho et al., 1992). According to Catton (1951), there is a progressive increase in the size of cells during the maturation of erythrocytes in teleost fish, while in mammals and birds there is a decrease in size. The blood parameters of $P$. mesopotamicus have shown a homogeneity of data, which can help in further comparing healthy and unhealthy individuals.

Satheeshkumar et al. (2012) suggested the regular use of blood profiles for wild fish, since blood collection does not kill the fish, and it can provide a rapid means for determining the physiological status of fish. According to Hlavová (1993) the information on the variability and dynamics of hematological parameters for fish is a prerequisite for the application of hematology in various fields of ichthyology. Another advantage from typifying the hematological profile of economically important fish is the establishing of a range of values. Those results can help in further studies, avoiding comparisons and using data from other regions, and reducing the need to use a large number of animals for each experiment.

\section{Acknowledgment}

The authors are thankful to Piscicultura Polettini (Mogi Mirim, SP, Brazil) for providing the fish, to the researchers of the Laboratório de Medicina Preventiva, Faculdade de Jaguariúna (Jaguariúna, SP, Brazil), and to our colleagues from the Laboratório de Ecossistemas Aquáticos, Embrapa Meio Ambiente (Jaguariúna, SP, Brazil) for their support during the experiment. This study was supported by the Ministério da Pesca e Aquicultura (Brazil).

\section{References}

Adams, S. M., K. D. Ham, M. S. Greeley, R. F. LeHew, D. E. Hinton \& C. F. Saylor. 1996. Downstream gradients in bioindicator responses: point source contaminant effects on fish health. Canadian Journal of Fisheries and Aquatic Sciences, 53: 21772187.

Azevedo, T. M. P., M. L. Martins, M. M. Yamashita \& C. J. Francisco. 2006. Hematologia de Oreochromis niloticus: comparação entre peixes mantidos em piscicultura consorciada com suínos e em pesque-pague no vale do rio Tijucas, Santa Catarina, Brasil. Boletim do Instituto de Pesca, 32: 41-49.

Borges, A. 2005. Valores hematológicos e bioquímicos séricos, efeitos de doses sub-letais da cipermetrina e características físico-químicas do sêmen do jundiá Rhamdia quelen. Unpublished Ph. D. Thesis, Universidade Federal do Rio Grande do Sul, Porto Alegre, 175p.

Boyd, C. E. 1990. Water quality in ponds for aquaculture. Auburne, USA, Alabama Agricultural Experiment Station, Auburn University, 482p.

Brasil. Ministério da Pesca e Aquicultura. 2012. Boletim Estatístico da Pesca e Aquicultura - Brasil.

Cameron, J. N. 1969. Seasonal changes in the ecology, respiration and hematology of the pinfish Lagodon rhomboids (Linnaeus) in Redfish Bay, Texas. Unpublished Ph. D. Thesis, University of Texas, Austin.
Campbell, T. W. \& F. Murru. 1990. An introduction to fish hematology. Compendium on Continuing Education for the Practicing Veterinarian, 12: 525-532.

Carvalho, E. G., C. S. Seibert, M. S. Coelho \& E. E. Marques. 2009. Parâmetros hematológicos de espécies nativas do rio Tocantins, Auchenipterus nuchalis, Psectrogaster amazonica e Squaliforma emarginata (Teleostei, Ostariophysi). Acta Scientiarum, Biological Sciences, 31: 173-177.

Catton, W. T. 1951. Blood cell formation in certain teleost fishes. Blood, 6: 39-60.

Falcon, D. R., M. M. Barros, L. E. Pezzato, W. V. N. Solarte \& I. G. Guimarães. 2008. Leucograma da Tilápia-do-Nilo arraçoada com dietas suplementadas com níveis de vitamina $\mathrm{C}$ e lipídeo submetidas a estresse por baixa temperatura. Ciência Animal Brasileira, 9: 543-551.

Fernandes, M. N. \& A. F. Mazon. 2003. Environmental pollution and fish gill morphology. Pp. 203-231. In: Val, A. L. \& B. G. Kapoor (Eds.). Fish adaptations. Enfield, Sciences Publishers.

Fletcher, G. L. 1975. The effects of capture, "stress" and storage of whole blood on the red blood cells, plasma proteins, glucose, and eletrolytes of the winter flounder (Pseudopleuronectes americanus). Canadian Journal of Zoology, 53: 197-206.

Gomes, L. C., J. I. Golombieski, A. R. C. Gomes \& B. Baldisserotto. 2000. Biologia do jundiá Rhamdia quelen (Teleostei, Pimelodidae). Ciência Rural, 30: 179-185.

Graham, M. S., R. L. Haedrich \& G. L. Fletcher. 1985. Hematology of three deep-sea fishes: a reflection of low metabolic rates. Comparative Biochemistry and Physiology, 80A: 79-84.

Hahn-Von-Hessberg, C. M., A. Grajales Quintero \& A. V. Gutiérrez-Jaramillo. 2011. Parámetros hematológicos de Tilapia nilótica (Oreochromis niloticus, Linnaeus 1757) con peso entre $250 \mathrm{~g}$ y $350 \mathrm{~g}$, en el Centro Experimental Piscícola de La Universidad de Caldas. Veterinaria y Zootecnia, 5: 4761.

Hansen, V. K. \& K. G. Wingstrand. 1960. Further studies on the non-nucleated erythrocytes of Maurolicus mulleri and comparisons with the blood cells of related fishes. Dana Report, 54: 1-22.

Hlavová, V. 1993. References values of the haematological indices in grayling (Thymallus thymallus Linnaeus). Comparative Biochemistry Physiology, 105A: 525-532.

Holland, R. A. B. 1970. Factors determining the velocity of gas uptake by intracellular hemoglobin. Pp. 1-23. In: Hershey, E. D. (Ed.). Blood oxygenation. New York, Plenum Press.

Holland, R. A. B. \& R. E. Forster. 1966. The effect of size of red cells on the kinetics of their oxygen uptake. The Journal of General Physiology, 49: 727-742.

Hrubec, T. C., J. L. Cardinale \& S. A. Smith. 2000. Hematology and plasma chemistry reference intervals for cultured tilapia (Oreochromis Hybrid). Veterinary Clinical Pathology, 29: 7-12.

Hrubec, T. C. \& S. A. Smith. 2010. Hematology of fishes. Pp. 994-1003. In: Weiss, D. J \& K. J. Wardrop (Eds.). Schalm's veterinary hematology. $6^{\text {th }}$ ed. Ames, Iowa, Wiley-Blackwell.

Ishikawa, N. M., M. J. T. Ranzani-Paiva \& J. V. Lombardi. 2008. Metodologia para quantificação de leucócitos totais em peixe, Oreochromis niloticus. Archives of Veterinary Science, 13: 54-63.

Jones, D. A. 1979. The importance of surface area/volume ratio to the rate of oxygen uptake by red cells. The Journal of General Physiology, 74: 643-646. 
Larsson, A., M. Johansson-Sjobeck \& R. Fange. 1976. Comparative study of some haematological and biochemical blood parameters in fishes from the Skagerrak. Journal of Fish Biology, 9: 425-440.

Leatherland, J. F., J. S. Ballantyne \& G. Van Der Kraak. 1998. Diagnostic assessment of non-infectious disorders of captive and wild fish populations and the use fish as sentinels organisms environmental studies. Pp. 335-366. In: Leatherland, J. S. \& P. Y. Woo (Eds.). Fish diseases and disorders. Massachusetts, Cab International.

Lima, F. C. T. 2003. Subfamily Bryconinae (Characins, Tetras). Pp. 174-181. In: Reis, R. E., S. O. Kullander \& C. J. Ferraris, Jr. (Orgs.). Check list of the freshwater fishes of South and Central America. Porto Alegre, Edipucrs.

Lorenz, E. K. 2010. Densidade de estocagem de Piracanjuba (Brycon orbigniannus) em tanques-rede de pequeno volume. Unpublished Ph. D. Dissertation, Universidade Estadual do Oeste do Paraná, Marechal Cândido Rondon, 70p.

Mahajan, C. L. \& J. S. Dheer. 1979. Cell types in the peripheral blood of air breathing fish Channa punctatus. Journal of Fish Biology, 14: 481-487.Natt, M. P. \& C. A. Herrick. 1952. A new blood diluent for counting the erythrocytes and leucocytes of the chicken. Poultry Science, 31: 735-738.

Radünz Neto, J. 1981. Desenvolvimento de técnicas de reprodução e manejo de larvas e alevinos de jundiá (Rhamdia quelen). Unpublished Master's thesis. Universidade Federal de Santa Maria, Santa Maria, 77p.

Ranzani-Paiva, M. J. T. \& A. T. Silva-Souza. 2004. Hematologia de peixes brasileiros. Pp. 89-120 In: Ranzani-Paiva, M. J. T., R. M. Takemoto \& M. L. A. P. Lizama (Orgs.). Sanidade de Organismo Aquáticos. São Paulo, Livraria Varela Editora.

Sampaio, F. G., C. L. Boijink, EL. R. B. Santos, A. L. Kalinin, A. J. B. Luiz \& F. T. Rantin. 2012. Antioxidant defenses and biochemical changes in the neotropical fish pacu, Piaractus mesopotamicus: responses to single and combined copper and hypercarbia exposure. Comparative Biochemistry and Physiology, Part C: Toxicology \& Pharmacology, 156: 178-186.

Satheeshkumar, P., G. Ananthan, D. Senthilkumar, A. B. Khan \& K. Jeevanantham. 2012. Comparative investigation on haematological and biochemical studies on wild marine teleost fishes from Vellar estuary, southeast coast of India. Comparative Clinical Pathology, 21: 275-281.

Smith, H. M. 1925. Cell size and metabolic activity in amphibia. The Biological Bulletin, 48: 347-378.
Smith, J. C. 1974. Studies on the blood and enzymes of fishes. Unpublished Ph. D. Thesis, Dalhousie University, Halifax.

Szarski, H. 1970. Changes in the amount of DNA in cell nuclei during vertebrate evolution. Nature, 226: 651-652.

Tavares-Dias, M. (Org.) 2009. Manejo e sanidade de peixes em cultivo. 1 ed. Macapá, Embrapa Amapá.

Tavares-Dias, M. \& M. I. Mataqueiro. 2004. Características hematológicas, bioquímicas e biométricas de Piaractus mesopotamicus Holmberg, 1887 (Osteichthyes: Characidae) oriundos de cultivo intensivo. Acta Scientiarum, Biological Sciences, 26: 157-162.

Tavares-Dias, M., J. F. B. Melo, G. Moraes \& F. R. Moraes. 2002. Características hematológicas de teleósteos brasileiros. IV. Variáveis do jundiá Rhamdia quelen (Pimelodidae). Ciência Rural, 32: 693-698.

Tavares-Dias, M. \& F. R. Moraes. 2004. Hematologia de peixes teleósteos. Ribeirão Preto, Villimpress Complexo Gráfico. 144p.

Tavares-Dias, M. \& F. R. Moraes. 2006. Hematological parameters for the Brycon orbignyanus Valenciennes, 1850 (Osteichthyes: Characidae) intensively bred. Hidrobiológica, 16: 271-274.

Tavares-Dias, M., S. H. C., M. L. Martins, E. D. Silva, F. R. Moraes \& D. Perecin. 1999. Hematologia de teleósteos brasileiros com infecção parasitária. I. Variáveis do Leporinus macrocephalus Garavello \& Britski, 1988 (Anastomidae) e Piaractus mesopotamicus Holmberg, 1887 (Characidae). Acta Scientiarum, Biological Sciences, 21: 337-342.

Thrall, M. A., D. C. Baker, T. W. Campbell, D. DeNicola, M. J. Fettman, E. D. Lassen, A. Rebar \& G. Weiser. 2007. Hematologia e bioquímica clínica veterinária. São Paulo, Roca. 582p.

Turrell, F. M. 1946. Tables of surfaces and volumes of spheres and of prolate and oblate spheroids, and spheroidal coefficients. $1^{\text {st }}$ Berkley, University of California Press. 153p.

Vácha, J. 1980. Problém normálnosti v biologii a lékařstvi. Praha, Avicenum. 177p.

Wilhelm Filho, D., G. J. Eble, G. Kassner, F. X. Caprario, A. L. Dafré \& M. Ohira. 1992. Comparative hematology in marine fish. Comparative Biochemistry Physiology, 102A: 311-321.

Submitted August 08, 2014 Accepted December 23, 2014 by Adalberto Val Published June 30, 2015 